\title{
DETERMINATION OF CYANOBACTERIAL COMPOSITION OF EYNAL (SIMAV) HOT SPRING IN KÜTAHYA, TURKEY
}

\author{
YILMAZ CANKILIÇ, M. \\ Anadolu University, Faculty of Sciences, Department of Biology, Eskisehir, Turkey \\ (phone: +9022233505 80; fax: +9022232049 10) \\ *Corresponding author \\ e-mail:meralyilmaz@anadolu.edu.tr \\ (Received $10^{\text {th }}$ May 2016; accepted $4^{\text {th }}$ Oct 2016)
}

\begin{abstract}
Cultural and molecular approaches were used to examine the cyanobacterial composition of Eynal (Simav) hot spring in Kütahya. Water and mat samples were collected for isolation in culture, microscopic morphological examination, and molecular diversity analysis based on 16S-23S ITS region sequences. Obtained different cyanobacterial morphotypes were identified, the most abundant of which were the members of Leptolyngbya and Oscillatoria genera. Different from classical identification, molecular analyses were allowed the detection of additional genus corresponded to Synechococcus, Geitlerinema, Phormidium, and filamentous thermophilic cyanobacterium. Overall diversity and morphological/genetic variation of thermophilic cyanobacteria are not as high as described from other hot springs. The results showed a low cyanobacterial diversity of Eynal hot spring, with only 10 operational taxonomic units (OTUs) per sample obtained by a combination of strain isolations, clone libraries and DGGE (Denaturing Gradient Gel Electrophoresis) based on 16S rRNA genes.
\end{abstract}

Keywords: thermophilic cyanobacteria, ARDRA (Amplified Ribosomal DNA Analysis), $16 S$ rRNA, cloning, DGGE, diversity

\section{Introduction}

Cyanobacteria are capable of living in a wide range of ecosystems such as oceans, freshwater systems, and also in many extreme environments like hypersaline settings, hyperarid desert areas, UV and ionizing radiation-exposed settings and even rock interiors (Garcia-Pichel et al., 1998; Wierzchos et al., 2006; Warren-Rhodes et al., 2006; Gorbushina and Broughton, 2009; Ragon et al., 2011), and also in thermal springs and their associated microbial mats (Castenholz, 2001). Thermophilic cyanobacteria are known to be interesting organisms in studies for basic and applied researches. It is believed that the ancestors of these living microorganisms were the oldest primary producers common in the distant past, and they perhaps used thermal springs as refugia (Gold, 1999; Plescia et al., 2001; Adhikary, 2006; Izagiurre et al., 2006; Hındák, 2008). Thermophilic cyanobacteria from the Yellowstone National Park were the first, and possibly the most extensively studied type of these group (Dyer and Gafford, 1961; Castenholz 1969; Brock 1967; Ward et al., 1998). On the other hand, although cyanobacteria from other thermal areas have also been explored to some extent, many remain have still been unstudied.

Hot springs are the exact model of habitats for taxa with 'subcosmopolitan' geographical distribution (Padisak, 2009). The geographical isolation of hot spring cyanobacteria resulted in evolutionary divergences on both global and local scales (Castenholz, 1996; Papke et al., 2003; Klatt et al., 2011). Phylogenetic relationships among cyanobacteria are not well understood yet. Molecular markers have potentially in the identification of field samples without culturing. So far, 16S rDNA has been widely 
used to infer phylogenetic relationships between species and strains as a single marker or combined with traditional techniques (Ishida et al., 2001; Li et al., 2001; Premanandh et al., 2006).

Turkey is one of the seven richest countries in the world with thermal sources. There are almost 1300 thermal springs throughout Anatolia. Kütahya is the richest area in Turkey with respect to geothermal waters in which eleven geothermal fields are above $30^{\circ} \mathrm{C}$. Simav is a region inside this area with geothermals characterized for their richness in chemical salts or minerals. This study presents the results of the cyanobacterial communities in Eynal (Simav) hot spring in Kütahya by using cultural and molecular diversity studies based on the amplification, cloning and sequencing of $16 \mathrm{~S}$ rRNA genes from enrichment cultures and natural samples.

\section{Materials and Methods}

\section{Sampling sites and physico-chemical analysis}

Eynal (Simav) hot spring (3907'32.46"N: 28 59'43.99"E; $805 \mathrm{~m}$ above sea level) in Kütahya was investigated (Figure 1). Sampling was carried out in May 2012. Thermal waters and mats for cyanobacterial cultures and molecular analysis were collected from two sampling sites in sterile glass vials and tubes and transported to the laboratory as soon as possible. Some physicochemical parameters such as water temperature, $\mathrm{pH}$, total dissolved solids (TDS) and dissolved oxygen were measured in the field using a WTW multiparameter probe and WTW OxiTop IS6. Potassium $\left(\mathrm{K}^{+}\right)$, Calcium $\left(\mathrm{Ca}^{2+}\right)$, Sodium $\left(\mathrm{Na}^{+}\right)$, Iron $\left(\mathrm{Fe}^{2+}\right)$, Manganese $(\mathrm{Mn})$, Magnesium $\left(\mathrm{Mg}^{2+}\right)$, Ammonium $\left(\mathrm{NH}_{4}^{+}\right)$, Fluorur $\left(\mathrm{F}^{-}\right)$, Nitrate $\left(\mathrm{NO}_{3}{ }^{-}\right)$, Sulfate $\left(\mathrm{SO}_{4}{ }^{2-}\right)$, Nitrogen dioxide $\left(\mathrm{NO}_{2}{ }^{-}\right)$, Bicarbonate $\left(\mathrm{HCO}_{3}{ }^{-}\right)$, Total $\mathrm{Cl}_{2}$, and Free $\mathrm{Cl}_{2}$, were measured with Spectrocuant ${ }^{\circledR}$ test kits (Merc). Values are provided in Table 1.
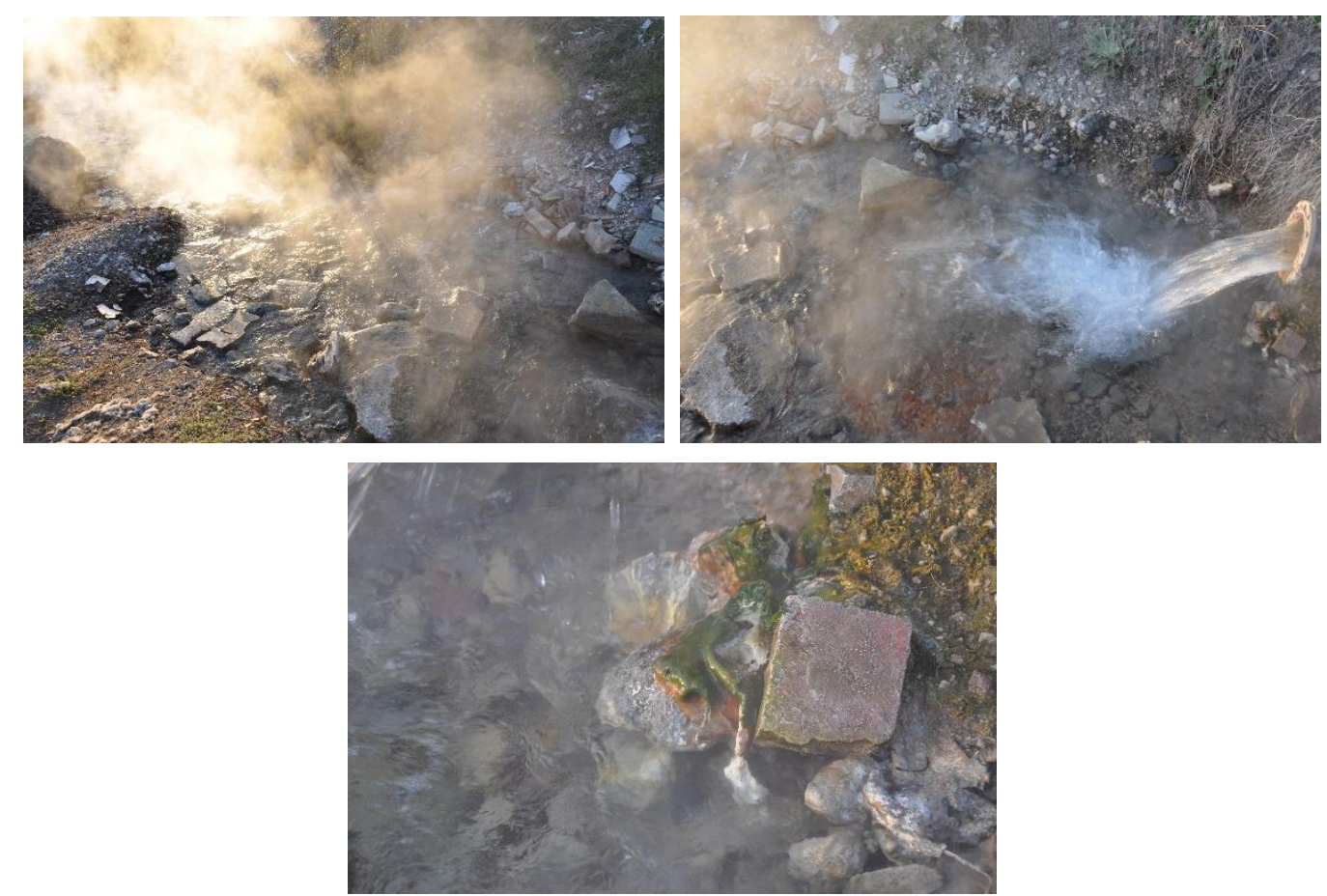

Figure 1. Eynal (Simav) hot spring 


\section{Morphological classification of cyanobacteria and enrichment cultures}

Morphological analysis of natural and cultivated cyanobacteria were performed based on observable characteristics under a light Olympos microscope BX51 equipped with digital microphoto-camera DP70. Morphotypes were identified to the genus level according to the identification systems proposed by Koma'rek and Anagnostidis, 1998, 2005, and Castenholz, 2001. Cultivation and isolation processes were conducted in BG11 medium including cycloheximide $\left(50 \mathrm{mg} \mathrm{L}^{-1}\right)$ to avoid eukaryotic contaminants using incubation temperatures at $55^{\circ} \mathrm{C}$ for several weeks until a green active biomass became visible and purification process was then performed. Subsequent cultures were incubated in the BG11 solid medium at $55^{\circ} \mathrm{C}$ (Boutte et al., 2005; Taton et al., 2006b).

\section{DNA purification, PCR amplification, cloning}

DNA was purified from cell pellets of homogenized microbial mats and enrichment cultures using the DNeasy ${ }^{\circledR}$ Plant Mini Kit (Qiagen) following manufacturer's instructions. Additionally, to obtain the total bacterial genomic DNA, firstly $500 \mathrm{ml}$ water samples were filtered on $0.2 \mu \mathrm{m}$-pore-size filters (Millipore). Filters placed in 15 $\mathrm{ml}$ sterile tubes containing $2 \mathrm{ml}$ lysis buffer (40 mM EDTA, $400 \mathrm{mM} \mathrm{NaCl}, 0.75 \mathrm{M}$ sucrose, $50 \mathrm{mM}$ Tris $\mathrm{HCl} \mathrm{pH}$ 8.3) (Giovannoni et al., 1990; Wilmotte et al., 2002). Enzymatic lysis and subsequent steps were carried out as described in Yilmaz and Arik, 2016. 16 rRNA gene libraries were constructed for all positive amplifications using the TopoTA cloning kit (Invitrogen, Carlsbad, CA, USA) according to the manufacturer's instructions. Plasmids were extracted and used to amplify the inserts with the cyanobacteria specific primers CYA359F and 23S30R as described above and subjected to ARDRA to screen the clone libraries.

\section{ARDRA (Amplified ribosomal DNA analysis)}

The 16S rRNA gene plus ITS amplicons obtained from the genomic DNA of the isolates and clones were used for ARDRA with two different restriction endonucleases, MspI and MboI (MBI Fermentas). All steps were performed as described previously (Scheldeman et al., 1999; Taton et al., 2003). The number of clones analyzed by ARDRA was 40, and 45 for two samples, respectively. The isolates and clones with a different restriction patterns were chosen for sequencing with the specific cyanobacterial reverse primers 23S30R (5'-CTTCGCCTCTGTGTGCCTAGGT-3'), 1492R (5'-GTA CGG CTA CCT TGT TAC GAC-3'), and 1092R (GCG CTC GTT GCG GGA CTT) by Macrogen (Seoul, Korea) and then these sequences were assembled.

\section{DGGE (Denaturing gradient gel electrophoresis) analysis}

Two successive PCR reactions were run to produce 422-bp long fragments, as described in Taton et al., 2003, except that electrophoresis was performed for $22 \mathrm{~h}$ at 80 $\mathrm{V}$ and $60^{\circ} \mathrm{C}$. Two DGGEs ( $\mathrm{a}$ and $\mathrm{b}$ ) were performed for each sample. The PCR primers were used according to Nübel et al., (1997) to carry out DGGE (a) and (b) targeted filamentous and unicellular cyanobacteria, respectively. The excised DGGE bands were incubated in $\mathrm{TE}^{-4}$ buffer for $12 \mathrm{~h}$ at $4^{\circ} \mathrm{C}$. Each solution was used as a template for PCR amplification as described above. The PCR products were then electrophoresed to 
confirm the bands and sequenced with primer 16S784R (5'-GGA CTA CWG GGG TAT CTA ATC CC-3').

\section{Sequence analysis}

16S rRNA gene sequences retrieved from samples were compared with sequences in the GenBank database (http://www.ncbi.nlm.nih.gov/) by BLAST search program at the National Center for Biotechnology Information website (http://www.ncbi.nlm.nih.gov). Obtained sequences were considered to belong to the same operational taxonomic unit (OTU) when they shared more than $97 \%$ identity. We retrieved the closest sequences found in databases and included them in an alignment containing also sequences from the closest cultivated members and some representative sequences of major cyanobacterial taxa. Sequences were aligned using BioEdit v7.2.5 software. All sequences were checked for chimera formation using the DECIPHER (Wright et al., 2012). CHECK-CHIMERA software developed by the Ribosomal Database Project and the phylogenetic affiliations of their $5^{\prime}$ and $3^{\prime}$ ends were compared. Phylogenetic trees were constructed using the maximum likelihood treeing algorithm and NearestNeighbor-Interchange (NNI) method in the MEGA 6 (Tamura et al., 2007). The Distance Matrix was calculated using the Jukes-Cantor correction. Validity of the tree topology was checked using the bootstrap method (1000 replicates). Newly identified sequences were deposited in GenBank with accession numbers KU937325-KU937339, KU950335, KU950336.

\section{Results}

\section{Physico-chemical parameters and mineral composition of hot spring waters}

The temperatures of Eynal spring thermal water was $97^{\circ} \mathrm{C}$. The $\mathrm{pH}$ of the analyzed water sample was 8.66, slightly alkaline and its total dissolved solids was $2.15 \mathrm{~g} / \mathrm{l}$. The results for concentration of major and minor components were listed in Table 1.

Table 1. Some properties of the water sample.

\begin{tabular}{|c|c|}
\hline Water sample & Eynal (Simav) \\
\hline Temperature & 97 \\
\hline $\mathrm{pH}$ & 8.68 \\
\hline Dissolved oxygen $(\mathrm{mg} / \mathrm{l})$ & 0.8 \\
\hline $\mathrm{TDS}(\mathrm{g} / \mathrm{l})$ & 1.6 \\
\hline $\mathrm{Mg}^{2+}(\mathrm{mg} / \mathrm{l})$ & 30.3 \\
\hline $\mathrm{K}^{+}(\mathrm{mg} / \mathrm{l})$ & 86.94 \\
\hline $\mathrm{Ca}^{2+}(\mathrm{mg} / \mathrm{l})$ & 80.99 \\
\hline $\mathrm{Na}^{+}(\mathrm{mg} / \mathrm{l})$ & 242.87 \\
\hline $\mathrm{Fe}^{2+}(\mathrm{mg} / \mathrm{l})$ & 0.21 \\
\hline $\mathrm{Mn}^{(\mathrm{mg} / \mathrm{l})}$ & 0.07 \\
\hline $\mathrm{NH}_{4}^{+}$ & $<0.5$ \\
\hline
\end{tabular}




\begin{tabular}{|c|c|}
\hline $\mathrm{F}^{-}(\mathrm{mg} / \mathrm{l})$ & 0.45 \\
\hline $\mathrm{NO}_{3}^{-}(\mathrm{mg} / \mathrm{l})$ & $<0.5$ \\
\hline $\mathrm{NO}_{2}^{-}(\mathrm{mg} / \mathrm{l})$ & 0.027 \\
\hline $\mathrm{SO}_{4}{ }^{2-}(\mathrm{mg} / \mathrm{l})$ & 155.90 \\
\hline $\mathrm{HCO}_{3}^{-}(\mathrm{mg} / \mathrm{l})$ & 466.35 \\
\hline Total $\mathrm{Cl}_{2}(\mathrm{mg} / \mathrm{l})$ & 0.16 \\
\hline Free $\mathrm{Cl}_{2}(\mathrm{mg} / \mathrm{l})$ & 0.12 \\
\hline
\end{tabular}

\section{Identification and enrichment of cyanobacterial morphospecies}

Morphological variability was studied in natural samples as well as in isolated strains. The filament variability was not extensive in natural samples. All strains produced singletrichome filaments with sheath and there was no false branching (Figure 2).

Cyanobacterial isolates were obtained from the two samples using BG11 media belonging to the order Oscillatoriales. No heterocystous or unicellular cyanobacterial isolates were detected by culturing in this study, although they have been observed in microscopy, Synechococcus and coccoid colonial Gleocapsa sp., due to because of their possible rareness in the environmental samples. All the cultivation studies were conducted in the same culture medium (BG11) including cycloheximide. The most abundant morphotypes were observed as the filamentous cyanobacteria that the Leptolyngbya genus.

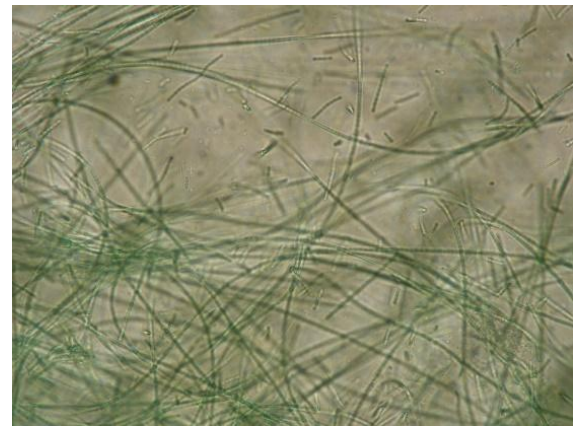

(a)

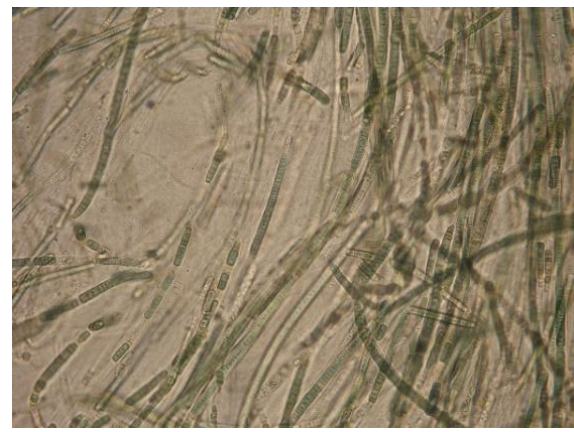

(c)

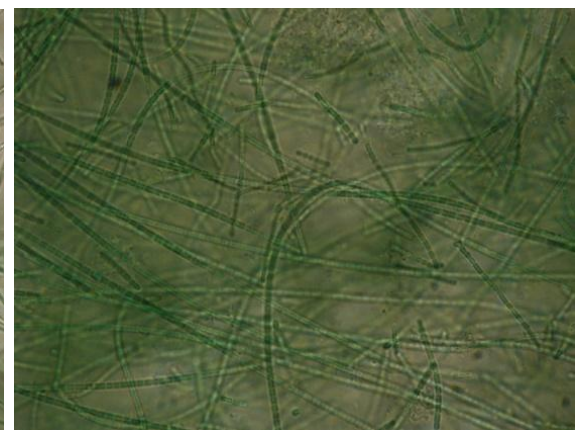

(b)

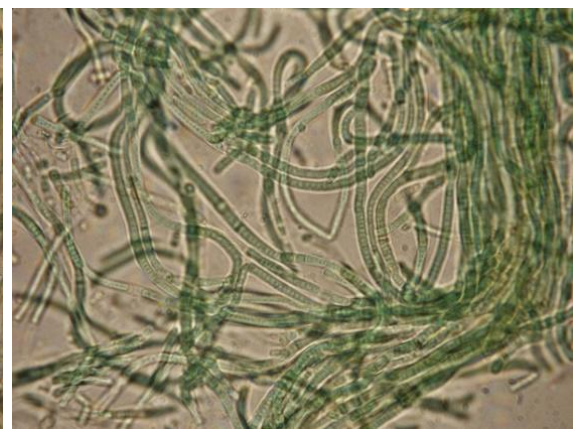

(d)

Figure 2. Light microscopy images of trichome morphology of some filamentous colonies $(a, b, c, d)$ in $B G-11$ medium (40X objective). 


\section{Diversity of cyanobacteria based on $16 S$ rRNA gene sequences}

Cyanobacterial diversity was studied also by amplification, cloning, DGGE and sequencing 16S rRNA genes from the enrichment cultures as well as from filters obtained from hot spring waters.

28 pure isolates with 3 different ARDRA profiles (Table 2) were obtained from the hot spring. In our ARDRA results, S3 cluster was found as dominant with $57.14 \%$ of the isolates. The regarding percentage of $\mathrm{S} 1$, and $\mathrm{S} 2$ are $25 \%$ and $17.85 \%$, respectively. The similarities among the isolates with the closest relative sequences in GenBank can be seen in Table 2. The sequence of the isolate K5 shows similarity with the Oscillatoriales cyanobacterium (OTU 16SEY1) isolated from LaDuke Hot Spring, Great Yellowstone area (Unpublished, Acc. Number FJ788926) and K9 is similar to the genus Leptolyngbya sp. (OTU 16SEY2) isolated from geothermal springs of Costa Rica (Unpublished, Acc. Number EF545616). K11 and K16 isolates show similarity with the genus Oscillatoria sp. (OTU 16SEY3) isolated from Tuwa hot-water spring, Panchmahal, Gujarat (Unpublished, Acc. Number JN661705.1). This molecular analysis should serve a comparison to previous researches that identified morphospecies with 16S rRNA gene-based operational taxonomic units (OTUs) and morphological studies.

In addition, cloning and DGGE techniques were also applied to determine cyanobacterial diversity of Eynal hot spring as culture-independent methods. A total of 113 clones containing inserts of the right size were obtained and 85 out of this were studied by ARDRA (16S plus ITS) and they differed in two restriction patterns that were $\mathrm{C} 1$, and $\mathrm{C} 2$ clusters. $\mathrm{C} 2$ cluster formed $57.64 \%$ of all the clones and was similar to Geitlerinema sp. (OTU 16SEY4) isolated from Afyonkarahisar hot spring (Yilmaz and Arik, 2016, Acc. Number KT715750.1). Similarly, C1 cluster was affiliated to same OTU as the C2 cluster although they had different ARDRA patterns.

In the DGGE study, a total of 16 positive DGGE bands (Figure 3) were obtained however only 10 of them could be sequenced. The most sequences obtained from the bands $(44.4 \%)$ yielded similarities to Geitlerinema sp. that was isolated from thermal waters in İzmir (Unpublished, Acc. Number HQ197683.1) with high percentages of similarity (99\%-100\%) and two bands, DGGECY2 and DGGECY3, were related to the Oscillatoria princeps isolated from Chao Phya, Thailand (Suda et al., 2002, Acc. Number AB045961), and Oscillatoria sp. isolated from hot spring of Thailand (Unpublished, Acc. Number EF452003.1). DGGECY10 and DGGECY11 bands were related to Phormidium sp. isolated from Euganean thermal springs, Padua, Italy (Berrini et al., 2004, Acc. Number AJ548503) and Baikal Rift Zone thermal spring, Russia (Unpublished, Acc. Number DQ408370), respectively. DGGECY4 and DGGECY6 bands were affiliated with Synechococcus sp. isolated from high altitude lakes in the Atacama Desert, Bolivia (Unpublished, Acc. Number EU729047.1) and Leptolyngbya orientalis isolated from hot water springs of north-western Himalayas, India (Unpublished, Acc. Number KM376987.1), respectively (Table 2). 
Table 2. Analysis of the 16S rRNA gene sequences obtained from Eynal hot spring

\begin{tabular}{|c|c|c|c|c|c|}
\hline & $\begin{array}{l}\text { Selected sequence } \\
\text { (Accession no)/ARDRA } \\
\text { Cluster }\end{array}$ & Closest BLAST strain hit & $\begin{array}{l}\text { Closest BLAST } \\
\text { uncultured hit }\end{array}$ & OTUs & $\begin{array}{l}\text { Origin of related } \\
\text { sequences outside } \\
\text { Kütahya }\end{array}$ \\
\hline \multirow{3}{*}{$\frac{\pi}{\frac{\pi}{\pi}}$} & $\begin{array}{l}\text { K5 (KU937325) } \\
\text { (S1 Cluster) }\end{array}$ & $\begin{array}{l}\text { Oscillatoriales cyanobacterium JSC- } \\
1 \text { (FJ788926.1) (99\%) }\end{array}$ & $\begin{array}{l}\text { Uncultured bacterium } \\
\text { clone YB-91 } \\
(\text { JQ769717.1) (98\%) }\end{array}$ & 16SEY1 & $\begin{array}{l}\text { Laduke Hot Spring, Great } \\
\text { Yellowstone }\end{array}$ \\
\hline & $\begin{array}{l}\text { K9 (KU937326) } \\
\text { (S2 Cluster) }\end{array}$ & $\begin{array}{l}\text { Leptolyngbya sp. CR_30M } \\
\text { (EF545616.1) (99\%) }\end{array}$ & $\begin{array}{l}\text { Uncultured bacterium } \\
\text { clone YB-91 } \\
(\text { JQ769717.1) (98\%) }\end{array}$ & 16SEY2 & $\begin{array}{l}\text { Geothermal Springs of } \\
\text { Costa Rica }\end{array}$ \\
\hline & $\begin{array}{l}\text { K11 (KU937327) } \\
\text { K16 (KU937328) } \\
\text { (S3 Cluster) }\end{array}$ & $\begin{array}{l}\text { Oscillatoria sp. N9DM } \\
\text { (JN661705.1) (99\%) }\end{array}$ & $\begin{array}{l}\text { Uncultured bacterium } \\
\text { clone B31_4 } \\
(\mathrm{KC} 831425.1)(99 \%)\end{array}$ & 16SEY3 & $\begin{array}{l}\text { Tuwa Hot-Water Spring, } \\
\text { Panchmahal, Gujarat }\end{array}$ \\
\hline \multirow{2}{*}{$\frac{\tilde{g}}{\frac{0}{0}}$} & $\begin{array}{l}\text { C126 (KU937331) } \\
\text { (C1 Cluster) }\end{array}$ & $\begin{array}{l}\text { Geitlerinema sp. CY20 } \\
(\mathrm{KT} 715750.1)(99 \%)\end{array}$ & $\begin{array}{l}\text { Uncultured } \\
\text { cyanobacterium clone } 15 \\
(\text { KT793921.1) }(99 \%)\end{array}$ & 16SEY4 & $\begin{array}{l}\text { Afyonkarahisar Hot } \\
\text { Spring }\end{array}$ \\
\hline & $\begin{array}{l}\text { C13 (KU937329) } \\
\text { C15 (KU937330) } \\
\text { (C2 Cluster) }\end{array}$ & $\begin{array}{l}\text { Geitlerinema sp. CY20 } \\
(\mathrm{KT} 715750.1)(99 \%)\end{array}$ & $\begin{array}{l}\text { Uncultured } \\
\text { cyanobacterium clone } 15 \\
(\text { KT793921.1) (99\%) }\end{array}$ & 16SEY4 & $\begin{array}{l}\text { Afyonkarahisar Hot } \\
\text { Spring }\end{array}$ \\
\hline \multirow{2}{*}{$\begin{array}{l}\frac{n}{0} \\
\\
0 \\
0 \\
0 \\
0 \\
0\end{array}$} & DGGECY1 (KU950335) & $\begin{array}{l}\text { Geitlerinema sp. Bal-2 } \\
\text { (HQ197683.1) (99\%) }\end{array}$ & $\begin{array}{l}\text { Uncultured } \\
\text { cyanobacterium clone } \\
13 \mathrm{~g} 08 \text { (GQ480593.1) } \\
(99 \%)\end{array}$ & 16SEY5 & Thermal Waters In İzmir \\
\hline & DGGECY5 (KU937334) & $\begin{array}{l}\text { Geitlerinema sp. Bal-2 } \\
\text { (HQ197683.1) (99\%) }\end{array}$ & $\begin{array}{l}\text { Uncultured } \\
\text { cyanobacterium clone } \\
\text { 13g08 (GQ480593.1) } \\
(99 \%)\end{array}$ & 16SEY5 & Thermal Waters in İzmir \\
\hline
\end{tabular}




\begin{tabular}{|c|c|c|c|c|}
\hline DGGECY8 (KU937336) & $\begin{array}{l}\text { Geitlerinema sp. Bal-2 } \\
\text { (HQ197683.1) }(99 \%)\end{array}$ & $\begin{array}{l}\text { Uncultured } \\
\text { cyanobacterium clone } \\
13 \mathrm{~g} 08 \text { (GQ480593.1) } \\
(99 \%)\end{array}$ & 16SEY5 & Thermal Waters in İzmir \\
\hline DGGECY9 (KU937337) & $\begin{array}{l}\text { Geitlerinema sp. Bal-2 } \\
(\mathrm{HQ197683.1)}(100 \%)\end{array}$ & $\begin{array}{l}\text { Uncultured } \\
\text { cyanobacterium clone } \\
13 \mathrm{~g} 08(\mathrm{GQ} 480593.1) \\
(100 \%)\end{array}$ & 16SEY5 & Thermal Waters in İzmir \\
\hline DGGECY2 (KU950336) & $\begin{array}{l}\text { Oscillatoria princeps NIVA-CYA } \\
(\mathrm{AB} 045961.1)(98 \%)\end{array}$ & $\begin{array}{l}\text { Uncultured bacterium } \\
\text { clone CU50 } \\
(\text { KF247920.1) (98\%) }\end{array}$ & 16SEY6 & Chao Phya, Thailand \\
\hline DGGECY3 (KU937332) & $\begin{array}{l}\text { Oscillatoria sp. PL51-2 } \\
\text { (EF452003.1) }(92 \%)\end{array}$ & $\begin{array}{l}\text { Uncultured Leptolyngbya } \\
\text { sp. clone Tsenher12otu4- } \\
1 \\
(\text { KT258783.1) }(92 \%)\end{array}$ & 16SEY7 & Hot Spring of Thailand \\
\hline DGGECY10 (KU937338) & $\begin{array}{l}\text { Phormidium sp. } 0417 \\
\text { (AJ548503) }(95 \%)\end{array}$ & $\begin{array}{l}\text { Uncultured } \\
\text { cyanobacterium clone } \\
\text { SE56 } \\
(\text { EU7289381.1) (\%97) }\end{array}$ & 16SEY8 & $\begin{array}{l}\text { Euganean Thermal } \\
\text { Springs, Padua, Italy }\end{array}$ \\
\hline DGGECY11 (KU937339) & $\begin{array}{l}\text { Phormidium sp. 0417 } \\
\text { (DQ408370.1) }(90 \%)\end{array}$ & $\begin{array}{l}\text { Uncultured } \\
\text { cyanobacterium clone } \\
\text { H1w-77 } \\
(\text { EF633001.1) (\%90) }\end{array}$ & 16SEY8 & $\begin{array}{l}\text { Baikal Rift Zone Thermal } \\
\text { Spring, Russia }\end{array}$ \\
\hline DGGECY4 (KU937333) & $\begin{array}{l}\text { Synechococcus sp. AECC1338 } \\
\text { (EU729047.1) (97\%) }\end{array}$ & $\begin{array}{l}\text { Uncultured } \\
\text { cyanobacterium clone } 21 \\
\text { (KT793924.1) (98\%) }\end{array}$ & 16SEY9 & $\begin{array}{l}\text { High Altitude Lakes in } \\
\text { The Atacama Desert, } \\
\text { Bolivia }\end{array}$ \\
\hline DGGECY6 (KU937335) & $\begin{array}{l}\text { Leptolyngbya orientalis PUPCCC } \\
112.18 \\
(\mathrm{KM} 376987.1)(98 \%)\end{array}$ & $\begin{array}{l}\text { Uncultured Leptolyngbya } \\
\text { sp. clone Tsenher12otu4- } \\
1 \text { (KT258783.1) } \\
(98 \%)\end{array}$ & 16SEY10 & $\begin{array}{l}\text { Hot Water Springs of } \\
\text { North-Western } \\
\text { Himalayas, India }\end{array}$ \\
\hline
\end{tabular}




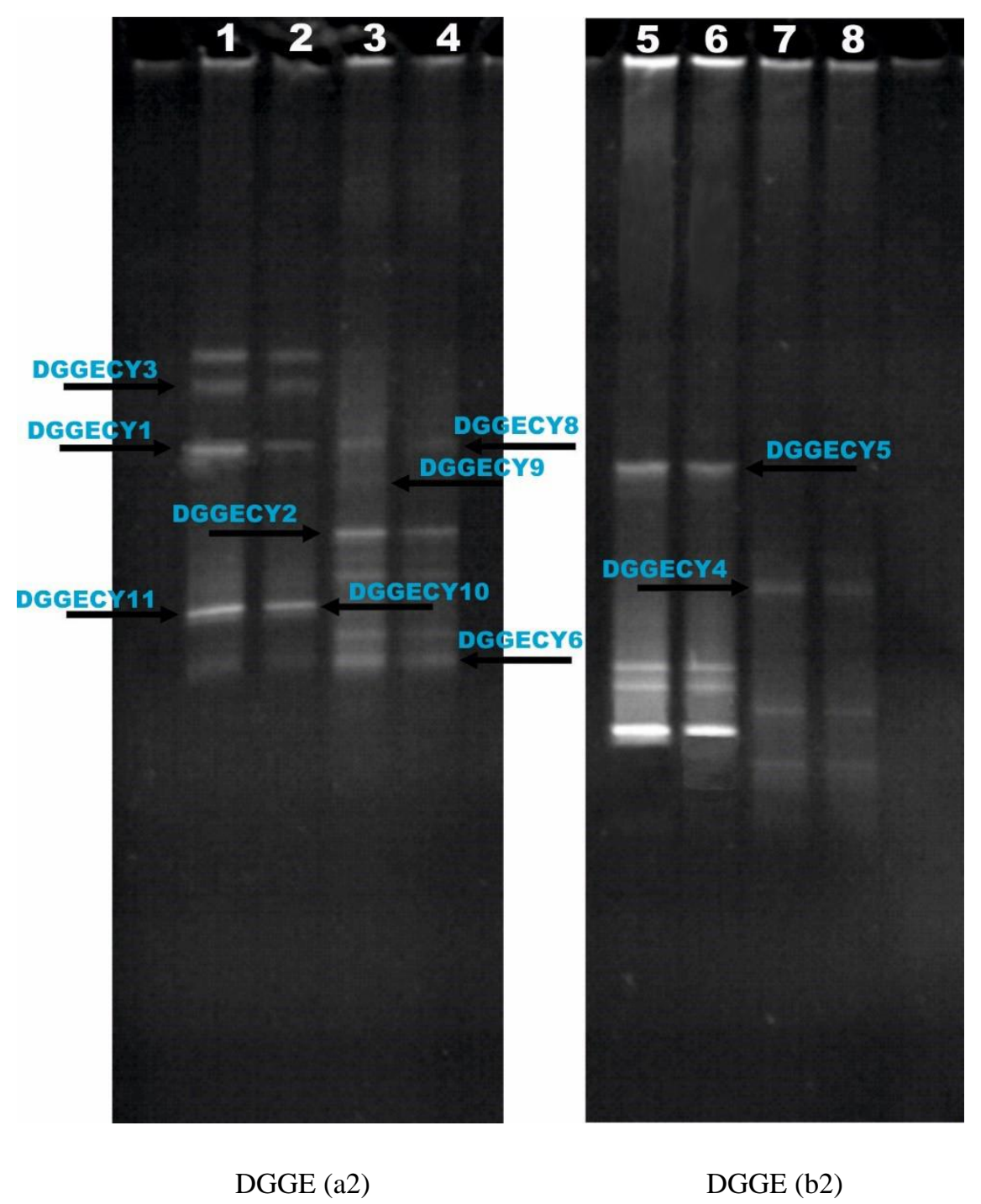

Figure 3. DGGE gels (a2) and (b2) of the hot springs and some positive major bands. (1), (2),

(5), (6) Eynal water sample, (3), (4), (7), (8) Eynal mat sample

\section{Phylogenetic analysis}

16S rRNA gene in gene libraries (Table 2), the phylogenetic position of isolates, clones and DGGE bands were demonstrated by the reconstruction of a phylogenetic tree (Figure 4, 5, 6). Aligned partial 16S rRNA gene sequences corresponding to E. coli sequence positions 498 to 1391 for the isolates, 465 to 1525 for the clones and 415 to 717 for the DGGE bands were used but the indels were not taken into account. Scale bar represents expected number of substitutions per site. Bootstrap support values below $50 \%$ were not included in the figures. 


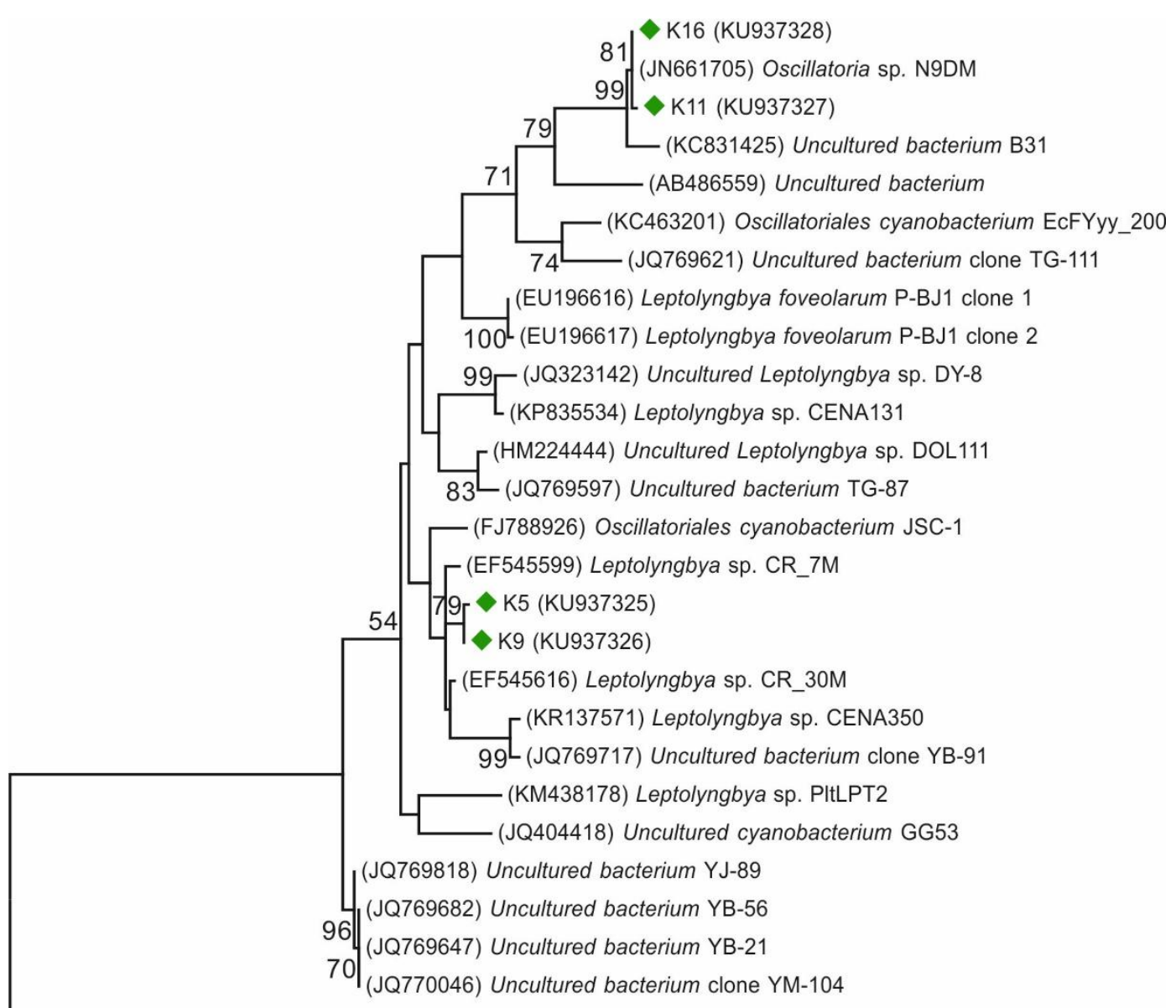

(CP009072) Escherichia coli; ATCC 25922

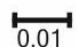

Figure 4. Phylogenetic inferences based on 16S rRNA gene sequences from isolates (indicated by green diamond).

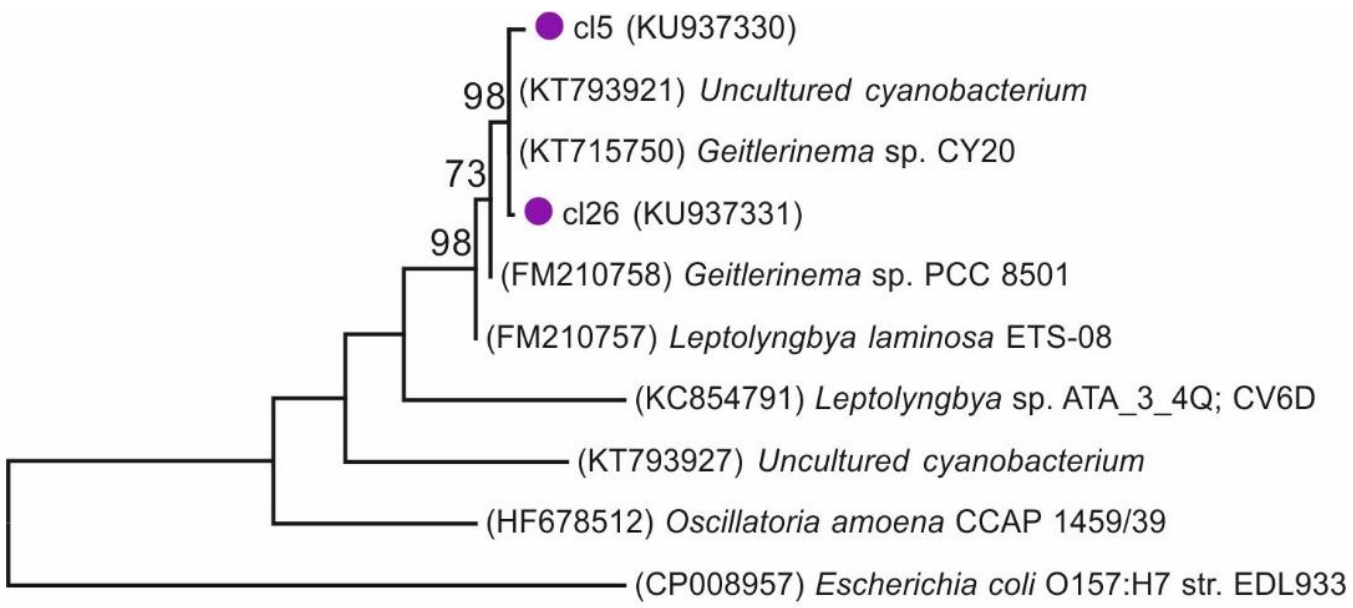

$\stackrel{5}{0.01}$

Figure 5. Phylogenetic inferences based on $16 S$ rRNA gene sequences from clones (indicated by violet circle) belonging to the cyanobacteria. 


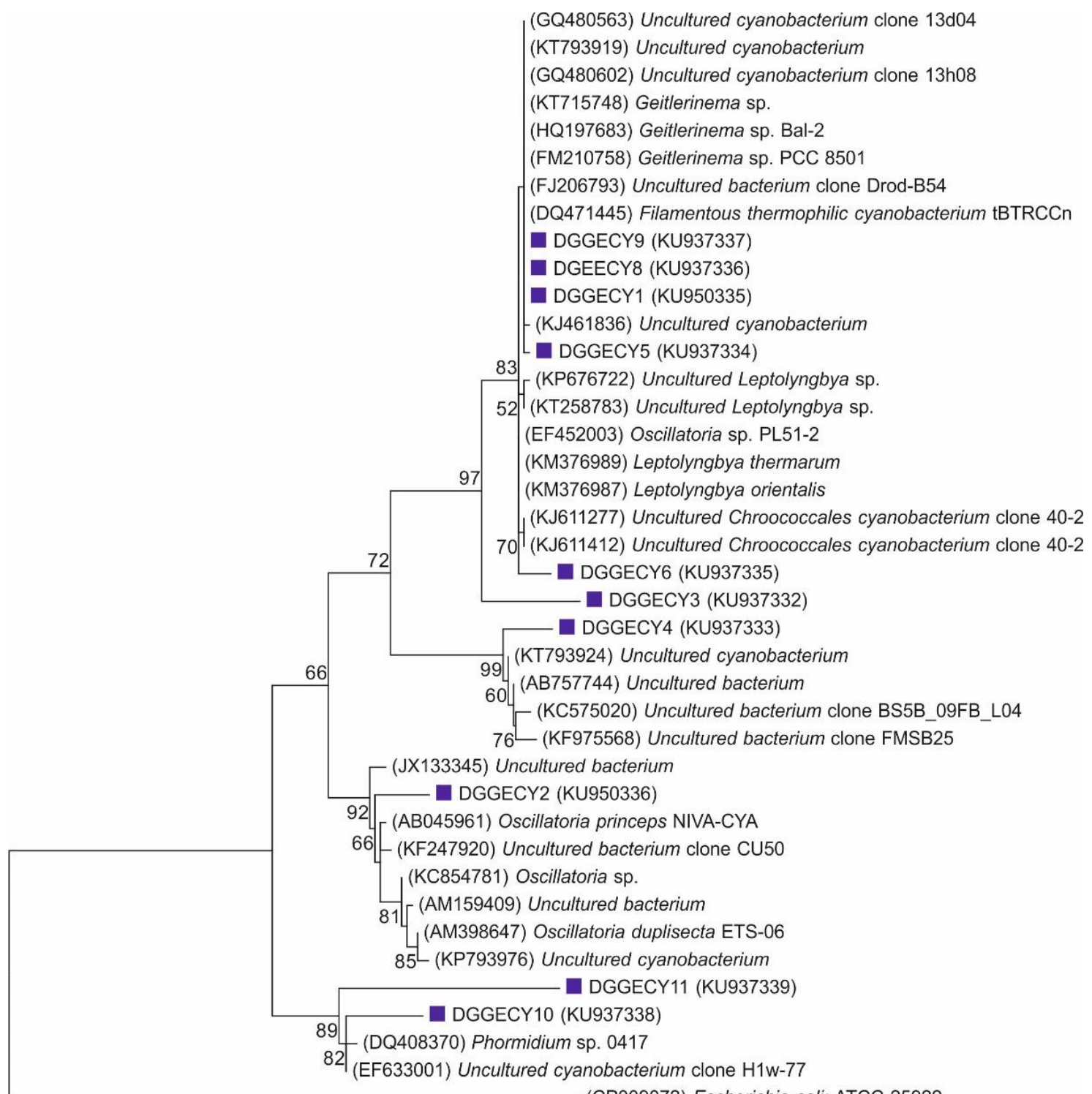

$\stackrel{501}{0.01}$

Figure 6. Phylogenetic inferences based on 16S rRNA gene sequences from some DGGE bands (indicated by blue square) belonging to the cyanobacteria.

\section{Conclusions}

In this study, cyanobacterial composition in Eynal (Simav) hot spring was determined by using cultivation and molecular methods such as cloning and DGGE. 16S rRNA sequences from hot springs on every side of the world have been intensively examined and studied using the mentioned methods above (Papke et al., 2003; Lau et al., 2005; Ward et al., 2006; McGregor and Rasmussen, 2008; Sompong et al., 2008; Oren et al., 2009; Ionescu et al., 2010). Hence it is possible to reveal the cyanobacterial diversity of the Eynal hot spring based on the 16S rRNA gene from molecular analysis. All the cultivation process were performed in the same culture medium (BG11) suggesting that, despite considerable differences in water and substrate chemistry, these cyanobacteria could fit to different environmental conditions (Yala et al., 2014). The 
filamentous cyanobacterial isolates obtained from Eynal hot spring waters and mat samples corresponded to Oscillatoriales members. In addition, cyanobacterial diversity was studied by amplification, cloning and sequencing 16S rRNA genes from the cultures as well as from environmental DNA of hot spring's water samples. These culture-independent methods were enabled to compare previously identified morphospecies with 16S rRNA gene-based operational taxonomic units (OTUs). 10 OTUs were identified with a combination of cultural and molecular methods. These OTUs affiliated to two order-level cyanobacterial clades, namely the Oscillatoriales that was dominant and Chroococcales. One of the dominant Eynal 16S rRNA gene sequences corresponded to the genus of filamentous cyanobacteria Leptolyngbya (e.g., Ionescu et al., 2010; Coman et al., 2013; Dadheech et al., 2013; Mackenzie et al., 2013; Yala et al., 2014) and Oscillatoria (e.g., Castenholz, 1967; Richardson and Castenholz, 1987; Castenholz 2015) that has been detected in hot springs worldwide. These sequences were obtained from isolates that were largely dominant in this mat sample but not from clones.

Geitlerinema, Phormidium, and Synechococcus sequences were determined with only molecular methods from water samples. This event has been previously reported (Taton et al., 2006a) and it is rightly due to the high sensitivity level of the molecular methods that could amplify DNA from rare morphotypes. Despite the fact that the DGGE was a less sensitive technique than clone libraries, several OTUs were retrieved by DGGE but not by clone library in this study. Indeed, only predominant populations can be detected by DGGE (Nikolausz et al., 2005), when their populations represent at least $1 \%$ of the total communities (Muyzer et al., 1993; Murray et al., 1996). Additionally, the ARDRA analyses used to screen the clone libraries could underestimate the diversity (Cho and Tiedje, 2000). In this study, there was not a clear correspondence between the isolates identified and the sequences retrieved. Casamatta et al., 2003 found various cyanobacteria like Pleurocapsa, Phormidium, Anabaena, Synechocystis, Oscillatoria, Microcoleus and Pseudanabaena with 16S rRNA gene sequences along with DGGE inhabiting Octopus hot spring. Similarly, Geitlerinema, Phormidium, Oscillatoria genus were also detected with DGGE in this study. One of the best-documented genera of thermophilic cyanobacteria was the genus Synechococcus (Dyer and Gafford, 1961; Castenholz, 1969; Ward et al., 1998; Miller and Castenholz, 2000; Ramsing et al., 2000; Papke et al., 2003; Ionescu et al., 2010). This sequence was not in the isolates, however it was detected only by DGGE. Consistent with cloning and DGGE, the 16S rRNA gene sequences from Eynal hot spring showed that Geitlerinema sequences were recovered and dominated from both methods. In contrast to our molecular results, Geitlerinema sp. was not obtained from culturing. Several authors have hypothesized that geographical isolation of hot springs leads to occurrence of indigenous thermophilic cyanobacteria (Castenholz, 1996; Papke et al., 2003; Miller et al., 2007; Finsinger et al., 2008). Our sequence analysis showed that Geitlerinema sp. sequences in Eynal (Simav) hot spring were phylogenetically distinct from those of the thermal/hot springs of other countries. Geitlerinema sp. sequences obtained in this study refer to the other sequences in GenBank that were obtained from Afyonkarahisar and İzmir hot springs in Turkey (Acc. Number KT715750.1 and HQ197683.1). Therefore, the observations confirm a speciation of Geitlerinema species inhabiting the hot springs in Turkey however it needs to be supported by further studies. Collectively, the diversity for hot spring water samples seems not to be compatible with findings of cultural and molecular analysis. 
Thermal springs represent pools of new strains possessing attractive biochemical pathways and unusual metabolic products for biotechnological applications like antimicrobial material, cancer drugs, ferredioxins, poly-b-hydroxybutyrate, and hydrogen production. (Fish and Codd, 1994; Javor, 1999; Mohamed, 2008; Miyake et al., 1996; Mitsui 1987).

There are no other studies analyzing the cyanobacterial composition in Eynal (Simav) hot spring. Therefore, isolation and identification of some of these thermophilic cyanobacteria isolates shall lead to the studies of their biology for future studies.

Acknowledgments. I am grateful to Kubilay Cankılıç for his help during field sampling. This work was financed by the Anadolu University Resarch Project No:1002F85.

\section{REFERENCES}

[1] Adhikary, S.P. (2006): Blue green algae, survival strategies in diverse environment. Pointer Publishers, Jaipur (Raj) India.

[2] Berrini, C.C., De Appolonia, F., Dalla Valle, L., Komarek, J., Andreoli, C. (2004): Morphological and molecular characterization of a thermophilic cyanobacterium (Oscillatoriales) from Euganean thermal springs (Padua, Italy). - Arch. Hyrdobiol. Suppl. Algol. Stud 113: 73-85.

[3] Boutte, C., Komárková, J., Grubisic, S., Znachor, P., Arnaud, B., Eliška, Z., Gullukaya, A., Jezberová, J., Wilmotte, A. (2005): A polyphasic approach to assess the cyanobacterial diversity of summer samples from Czech reservoirs. - Algol Stud 117: 177-195.

[4] Brock, T.D. (1967): Life at high temperatures. - Science 158(3804):1012-1019.

[5] Casamatta, D.A, Vis, M.L, Sheath, R.G. (2003): Cryptic species in cyanobacterial systematics: a case of Phormidium retzii (Oscillatorailes) using RAPD molecular markers and 16S rDNA Sequence data. - Aquatic Bot 77: 295-309.

[6] Castenholz, R.W. (1967): Aggregation in a thermophilic Oscillatoria. - Nature 215: $1285-1286$.

[7] Castenholz, R.W. (1969): Thermophilic blue-green algae and the thermal environment. Bacteriol Rev 33(4):476-504.

[8] Castenholz, R.W. (1996): Endemism and biodiversity of thermophilic Cyanobacteria. Nova Hedwigia 112: 33-47.

[9] Castenholz, R.W. (2001): Phylum BX. Cyanobacteria: oxygenic photosynthetic bacteria. In: Boone DR, Castenholz RW (eds) Bergey's manual of systematic bacteriology, vol 1, 2nd edn. Springer, New York, pp 473-599.

[10] Castenholz, R.W. (2008): Le ro^le des cyanobacte'ries et autres phototrophes dans les e' cosyste'mes des sources chaudes. - Press Therm Climat 145:129-134.

[11] Castenholz, R.W. (2015): Portrait of a Geothermal Spring, Hunter's Hot Springs, Oregon. - Life 5: 332-347.

[12] Cho, J.C., Tiedje, J.M. (2000): Biogeography and degree of endemicity of fluorescent Pseudomonas strains in soil. Applied and Environmental Microbiology 66: 5448-5456.

[13] Coman, C., Druga, B., Hegedus, A., Sicora, C., Dragos, N. (2013): Archaeal and bacterial diversity in two hot spring microbial mats from a geothermal region in Romania. Extremophiles 17(3): 523-534.

[14] Dadheech, P.K., Glockner, G., Casper, P., Kotut, K., Mazzoni, C.J, Mbedi, S., Krienitz, L. (2013): Cyanobacterial diversity in the hot spring, pelagic and benthic habitats of a tropical soda lake. - FEMS Microbiol Ecol 85(2): 389-40. 
[15] Dyer, D.L., Gafford, R.D. (1961): Some characteristics of a thermophilic blue-green alga. Science 134(3479):616-617. doi:10.1126/science.134.3479.616.

[16] Finsinger, K., Scholz, I., Serrano, A., Morales, S., Uribe-Lorio, L., Mora, M., Sittenfeld, A., Weckesser, J., Hess, W.R. (2008): Characterization of true-branching cyanobacteria from geothermal sites and hot springs of Costa Rica. - Environ Microbiol 10: 460-473.

[17] Fish, S.A., Codd, G. A. (1994): Bioactive compound production by thermophilic and thermotolerant cyanobacteria (blue-green algae). - World Journal of Microbiology and Biotechnology 10: 338-341.

[18] Garcia-Pichel, F., Nubel, U., Muyzer, G. (1998): The phylogeny of unicellular, extremely halotolerant cyanobacteria. - Arch Microbiol 169(6): 469-482.

[19] Giovannoni, S.J., DeLong, E.F., Schmidt, T.M., Pace, N.R. (1990): Tangential flow filtration and preliminary phylogenetic analysis of marine picoplankton. - Appl. Environ. Microbiol 56: 2572- 2575 .

[20] Gold, T., (1999): The deep hot biosphere: the myth of fossil fuels. 235 pp. Springer Verlag.

[21] Gorbushina, A.A., Broughton, W.J. (2009): Microbiology of the atmosphere-rock interface: how biological interactions and physical stresses modulate a sophisticated microbial ecosystem. - Annu Rev Microbiol 63:431-450.

[22] Hindák, F. (2008): On Chlorogloeopsis fritschii (Cyanophyta/Cyanobacteria) from thermal springs in Slovakia and from saline lake in Tunisia. - Algological Studies 126: $47-64$.

[23] Ionescu, D., Hindiyeh, M., Malkaw,i H., Aharon, O. (2010): Biogeographyof thermophilic cyanobacteria: insights from the ZerkaMa'in hot springs (Jordan). - FEMS Microbiol Ecol 72: 103-113.

[24] Ishida, T., Watanabe, M.M., Sugiyama, J., Yokota A. (2001): Evidence for polyphyletic origin of the members of the orders of Oscillatoriales and Pleurocapsales as determined by $16 \mathrm{~S}$ rDNA analysis. - FEMS Microbiol Lett 201: 79-82.

[25] Izagiurre, I., Allende, L., Tell, G. (2006): Algal communities of a geothermally heated lagoon on Deception Island (South Shetlands Islands). - Polar Biology 29: 364-371.

[26] Javor, B. J., 1999: Cancer drugs from thermophilic cyanobacteria. Grant National Cancer Institute. http://www.researchcrossroads.org/index.php?view=article\&id=50\%3Agrantdetails\&option=com_content\&Itemid=37\&grant_id=2626930. Access: 27.11.2009.

[27] Klatt, C.G., Wood, J.M., Rusch, D.B et al., (2011): Community ecology of hot spring cyanobacterial mats: predominant populations and their functional potential. - ISME J 5: $1262-1278$.

[28] Komarek, J., Anagnostidis, K. (1998): Cyanoprokaryota 1. Chroococcales, Vol. 19/1 (Ettl H, Gartner G, Heynig H \& Mollenhauer D, eds), pp. 1-548. Spectrum Academischer Verlag, Elsevier, Muunchen.

[29] Komarek, J., Anagnostidis, K. (2005): Cyanoprokaryota 2. Oscillatoriales, Vol. 19/2 (Budel B, Gartner G, Krienitz L., Schagerl M, eds), pp. 1-757. Spectrum Academischer Verlag, Elsevier, Munchen.

[30] Lau, E., Nash, C.Z., Vogler, D.R., Cullings, K.W. (2005): Molecular diversity of cyanobacteria İnhabiting coniform structures and surrounding mat in a yellowstone hot spring. - Astrobiology 5(1): 83-92.

[31] Li, R.H., Debella, H.J., Carmichael, W.W. (2001): Isolates identifiable as Arthrospira maxima and Arthrospira fusiformis (Oscillatoriales, Cyanobacteria) appear identical on the basis of a morphological study in culture and 16S rRNA gene sequences. - Phycologia 40: 367-371.

[32] Mackenzie, R., Pedros-Alio, C., Diez, B. (2013): Bacterial composition of microbial mats in hot springs in Northern Patagonia: variations with seasons and temperature. Extremophiles 17(1):123-136. 
[33] Mcgregor, G.B., Rasmussen. J.P. (2008): Cyanobacterial composition of microbial mats from an Australian thermal spring: a polyphasic evaluation. - FEMS Microbiol Ecol 63: $23-35$.

[34] Mohamed, Z.A. (2008): Toxic cyanobacteria and cyanotoxins in public hot springs in Saudi Arabia. - Toxicon 51: 17-27.

[35] Miller, S.R., Castenholz, R.W. (2000): Evolution of thermotolerance in hot spring cyanobacteria of the genus Synechococcus. - Appl Environ Microb 66: 4222-4229.

[36] Miller, S.R, Castenholz, R.W, Pederson, D. (2007): Phylogeography of the thermophilic cyanobacterium Mastigocladus laminosus. - Appl Environ Microb 73: 4751-4759.

[37] Mitsui, A., (1987): Photobiological production of hydrogen from water and waste. Proceedings of the hydrogen photo-production workshop. Hawaii Natural Energy Institute University of Hawaii at Manoa, Honolulu, Hawaii, 1-51.

[38] Miyake, M., Erata, M., Asada, Y. (1996): A thermphilic cyanobacterium, Synechococcus sp.MA19, capable of accumulating poly-a-hydroxybutylrate. - Journal of Fermentation and Bioengeneering 82: 512-514.

[39] Murray, A.E., Hollibaugh, J.T., Orrego, C. (1996): Phylogenetic compositions of bacterioplankton from two California estuaries compared by denaturing gradient gel electrophoresis of 16S rDNA fragments. - Applied and Environmental Microbiology 62: 2676-2680.

[40] Muyzer, G., Dewaal, E.C., Uitterlinden, A.G. (1993): Profiling of Complex MicrobialPopulations by Denaturing Gradient Gel-Electrophoresis Analysis of Polymerase Chain Reaction-Amplified Genes-Coding for 16s Ribosomal-RNA. - Applied and Environmental Microbiology 59: 695-700.

[41] Nikolausz, M., Sipos, R., Revesz, S., Szekely, A., Marialigeti, K. (2005): Observation of bias associated with re-amplification of DNA isolated from denaturing gels. - FEMS Microbiol. Lett. 244: 385-390.

[42] Nübel, U., Garcia-Pichel, F., Muyzer, G. (1997): PCR primers to amplify 16S rRNA genes from cyanobacteria. - Applied and Environmental Microbiology 63: 3327-3332.

[43] Oren, A., Ionescu, D., Hindiyeh, M.Y., Hanan, I.M. (2009): Morphological, phylogenetic and physiological diversity of cyanobacteria in the hot springs of Zerka Ma'in, Jordan. BioRisk 3: 69-82.

[44] Padisak, J. (2009): The phycogeography of freshwater algae. Encyclopedia of Inland Waters, Vol. I (Likens G, ed.), pp. 219-223. Elsevier, Inc., Oxford.

[45] Papke, R.T., Ramsing, N.B., Bateson, M.M., Ward, D.M. (2003): Geographical isolation in hot spring cyanobacteria. - Environ Microbiol 5: 650-659.

[46] Plescia, J.B., Johnson, J.R., Ferris, M. (2001): Visible-near infrared spectroscopy of hyperthermophile organisms, Yellowstone National Park. - Proceedings of Abstracts General Meeting of the NASAAstrobiology Institute, Carnegie Institution of Washington, Washington, DC, 129-130.

[47] Premanandh, J., Priya, B., Teneva, I., Dzhambazov, B., Prabaharan, D., Uma, L. (2006): Molecular characterization of marine cyanobacteria from the Indian subcontinent deduced from sequence analysis of the phycocyanin operon (cpcB-IGScpcA) and 16S-23S ITS region. - J Microbiol 44: 607-616.

[48] Ragon, M., Restoux, G., Moreira, D., Moller, A.P., Lopez-Garcia, P. (2011): Sunlightexposed biofilm microbial communities are naturally resistant to Chernobyl ionizingradiation levels. - PLoS One 6(7): e21764. doi:10.1371/journal.pone.0021764.

[49] Ramsing, N.B., Ferris, M.J., Ward, D.M. (2000): Highly ordered vertical structure of Synechococcus populations within the onemillimeter-thick photic zone of a hot spring cyanobacterial mat. - Appl Environ Microb 66: 1038-1039.

[50] Richardson, L.L., Castenholz, R.W. (1987): Diel Vertical Movements of the Cyanobacterium Oscillatoria terebriformis in a Sulfide-Rich Hot Spring Microbial Matt. Applied and Environmental Microbiology Sept 53(9): 2142-2150. 
[51] Scheldeman, P., Baurain, D., Bouhy, R., Scott, M., Muhling, M., Whitton, B.A., Belay, A., Wilmotte, A. (1999): Arthrospira ('Spirulina') strains from four continents are resolved into only two clusters, based on amplified ribosomal DNA restriction analysis of the internally transcribed spacer. - FEMS Microbiol Lett 172: 213-222.

[52] Sompong, U., Anuntalabhochai, S., Cutler, R.W., Castenholz R.W., Peerapornpisal Y., (2008), Morphological and phylogenic diversity of cyanobacterial populations in six hot springs of Thailand, - ScienceAsia 34: 153-162.

[53] Suda, S., Watanabe, M.M., Otsuka, S., Mahakahant, A., Yongmanitchai, W., Nopartnaraporn, N., Liu, Y. And Day, J.G. (2002): Taxonomic revision of water-bloomforming species of Oscillatorioid cyanobacteria. - Int.J.Syst. Evol.Microbiol 52(5): 15771595.

[54] Tamura, K., Dudley, J., Nei, M., Kumar, S. (2007): MEGA4: Molecular Evolutionary Genetics Analysis (MEGA) software version 4.0. - Molecular Biology and Evolution 24: 1596-1599.

[55] Taton, A., Grubisic, S., Brambilla, E., De Wit, R., Wilmotte, A. (2003): Cyanobacterial diversity in natural and artificial microbial mats of Lake Fryxell (McMurdo Dry Valleys, Antarctica): a morphological and molecular approach. - Appl. Environ. Microbiol 69: 5157-5169.

[56] Taton, A., Grubisic, S., Balhasart, P., Hodgson, D.A., Laybourn-Parry, J., Wilmotte, A. (2006a): Biogeographical distribution and ecological ranges of benthic cyanobacteria in East Antarctic lakes. - FEMS Microbiol Ecol 57: 272-289.

[57] Taton, A., Grubisic, S., Ertz, D. (2006b): Polyphasic study of Antarctic cyanobacterial strains. - J Phycol 42: 1257-1270.

[58] Ward, D.M., Ferris, M.J., Nold, S.C., Bateson, M.M. (1998): A natural view of microbial biodiversity within hot spring cyanobacterial mat communities. - Microbiol Mol Biol Rev 62(4):1353-1370.

[59] Ward, D.M., Bateson, M.M., Ferris, M.J., Kuhl, M., Wieland, A., Koeppel, A., Cohan, F.M. (2006): Cyanobacterial ecotypes in the microbial mat community of Mushroom Spring (Yellowstone National Park, Wyoming) as species-like units linking microbial community composition, structure and function. - Philos Trans R Soc B 361: 1997-2008.

[60] Warren-Rhodes, K.A, Rhodes, K.L., Pointing, S.B., Ewing, S.A., Lacap, D.C., GomezSilva, B., Amundson, R., Friedmann, E.I, McKay, C.P. (2006): Hypolithic cyanobacteria, dry limit of photosynthesis, and microbial ecology in the hyperarid Atacama Desert. Microb Ecol 52(3): 389-398.

[61] Wierzchos, J., Ascaso, C., McKay, C.P. (2006): Endolithic cyanobacteria in halite rocks from the hyperarid core of the Atacama Desert. - Astrobiology 6(3):415-422.

[62] Wilmotte, A., Demonceau, C., Goffart, A., Hecq, J.H., Demoulin, V., Crossley, A.C. (2002): Molecular and pigment studies of the picophytoplankton in a region of the Southern Ocean (428-548 S, 1418-1448 E) in March 1998. - Deep-Sea Res., Part 2, Top. Stud. Oceanogr. 49: 3351-3363.

[63] Wright, E.S et al (2012): DECIPHER, A Search-Based Approach to Chimera Identification for 16S rRNA Sequences. Applied and Environmental Microbiology.

[64] Yala, S.A., Benouadah, A., Bentabet, A.E.O., Lopez-Garcia, P. (2014): Morphological and phylogenetic diversity of thermophilic cyanobacteria in Algerian hot springs. Extremophiles, 18:1035-1047.

[65] Yilmaz, C.M., Arik, B.G. (2016): Analysis of cyanobacterial diversity of some hot springs in Afyonkarahisar, Turkey. - Applied Ecology and Environmental Research 14(2): 463-483. 